\title{
Luminespib Mesylate
}

National Cancer Institute

\section{Source}

National Cancer Institute. Luminespib Mesylate. NCI Thesaurus. Code C162567.

The mesylate salt of luminespib, a derivative of 4,5-diarylisoxazole and a third-generation heat shock protein 90 (Hsp90) inhibitor with potential antineoplastic activity. Upon administration, luminespib binds with high affinity to and inhibits Hsp90, resulting in the proteasomal degradation of oncogenic client proteins; the inhibition of cell proliferation; and the elevation of heat shock protein $72(\mathrm{Hsp} 72)$ in a wide range of human tumor cell lines. Hsp90, a 90 kDa molecular chaperone, plays a key role in the conformational maturation, stability and function of other substrate or "client" proteins within the cell, many of which are involved in signal transduction, cell cycle regulation and apoptosis, including kinases, transcription factors and hormone receptors. Hsp72 exhibits antiapoptotic functions; its up-regulation may be used as a surrog ate marker for Hsp90 inhibition. 